\title{
Towards an Embodied Critical Pedagogy of Discomfort as a Decolonising Teaching Strategy
}

\author{
Sylvan Blignaut \\ ORCID iD: https://orcid.org/0000-0002-5514-0604
}

\section{Oscar Koopman \\ ORCID iD: https://orcid.org/0000-0002-1508-3967}

\begin{abstract}
In this paper, we recount the first author's experiences of exploring a critical pedagogy of discomfort as a way of practising social justice during a series of classes with a group of predominantly white Postgraduate Certificate in Education (PGCE) students. The primary focus of these classes was on issues related to race, racism, privilege, and inequality. A qualitative approach was adopted for the data collection process in which the researcher took on the role of a participant observer. Ethnographic fieldnotes were used as the main source of data. In our analysis of the first author's experiences, we discuss the difficulties and challenges he faced in adopting this pedagogical approach. After reporting on these challenges and difficulties we argue that cultivating social justice through a critical pedagogy of discomfort as a form of decolonisation is not enough to counteract an education that promotes instrumentalisation and the commodification of knowledge. Accordingly, we argue for a shift towards an embodied critical pedagogy of discomfort that takes into account an acute awareness (epistemological and ontological) of embodiment to serve as a decolonising teaching strategy.
\end{abstract}

Keywords: critical pedagogy, curriculum transformation, decolonisation, embodiment, higher education, racism 


\section{Introduction: Against Uncritical Learning}

Most of the policy documents on curriculum transformation both in the schooling sector as well as in teacher education after 1994 foreground an education for social justice as an essential element in addressing and reversing the legacies of apartheid education. To support this claim, Ramrathan (2010: 107) writes,

Since 1994, there has been a proliferation of new policies and changes to the education system that have had a major impact on the teaching context and schools. Statements of social justice, equity, redress, human rights, healthy environment, and quality are found in the introduction and background of almost all policy documents, gazettes, and regulations within education.

In addition to these policy changes, to set the stage for developing teacher education programmes to advance critical learning, Waghid (2010) explains how the various programmes already in existence such as the B. Ed., PGCE, and M.Ed. programmes had to be reviewed to comply with the principles adopted by the Council on Higher Education (CHE) and the Higher Education Quality Committee (HEQC) for a coherent and integrated focus on promoting critical learning. Our personal experiences of teaching in the various teacher education programmes such as the undergraduate B. Ed. and postgraduate qualifications such as the PGCE programme at the universities at which we work it is evident that much uncritical learning takes place and, in agreement with Waghid (2010: 202), we often observe how 'students seem to have become consumed with a market-orientated logic of learning'. Consequently, we feel that it is essential for teacher education programmes in a postcolonial society such as South Africa, where the legacy of the past is still evident in every facet of life, to ensure that students become more vocal and critical about issues such as racism, privilege, and inequality if they are to become effective practitioners of social justice. If teacher educators do not undertake this important task of focusing critically on social justice, their students will run the risk of perpetuating racism, stereotypes, and existing inequalities and thereby reproduce the old prevailing hegemony and the existing social order characterised by inequity and injustice. 
Teacher education, therefore, has an important role to play in ascertaining what counts as knowledge and how this knowledge is produced to instil in future teachers the anti-hegemonic discourses that counteract racebased social inequality as well as provide a corrective to the abuses of power and privilege in society. Pre-service teachers need to engage critically with issues of race as well as explore and reflect on their racial identities so that they might come to understand how these identities have been shaped by past experiences and determine how these experiences play out in the ways in which they interpret the present.

To begin to outline the development of a critical pedagogy that takes into account the personal lived realities of students through an epistemology of being, the first part of the paper recounts the first author's experiences in exploring a critical pedagogy of discomfort, aimed at practising social justice through a series of classes on issues that dealt with racism, privilege, and inequality with a group of mainly white PGCE students. In our analysis of the first author's experiences, we discuss the difficulties and challenges he faced in adopting this pedagogical approach. After reporting on these challenges and difficulties we argue that a critical pedagogy of discomfort is not enough to counteract education that promotes instrumentalisation and commodification of knowledge if, as a form of decolonisation, we are to cultivate social justice. Accordingly, we argue for an embodied critical pedagogy of discomfort, that takes into account an acute awareness (epistemological and ontological) of embodiment that can serve as a decolonising teaching strategy.

\section{Theoretical Framework}

Over the last five years, through the Fallism movement, we have witnessed how the student demand for a decolonised curriculum in universities has become almost inescapable, forcing government and university administrators to the negotiating table to commit to the demand that the university curriculum be decolonised (Le Grange 2016). From a pedagogical perspective, scholars like Ogunniyi (2007), Koopman (2019), and Iwuanyanwu and Ogunniyi (2020), and various others have argued that a decolonised classroom space requires a shift away from an authoritative pedagogy to a more democratic participative critical one that gives voice to the lived realities of students. For example, Koopman (2019) argues that in a decolonised pedagogical space, 
academics should open the classroom to dialogue through the curriculum to develop new ways of seeing that are different from those of dominant pedagogical discourses that promote what Waghid (2010) calls a consumerist logic or, put differently, a factual knowledge from textbooks that must be regurgitated in tests and examinations. Iwuanyanwu and Ogunniyi (2020) argue for an instructional approach that encourages dialogical argumentation as a decolonising teaching strategy to disrupt uncritical learning. In other words, to prevent students from becoming passive consumers of knowledge, their everyday lived realities must be at the centre of critical pedagogical engagement. We are aware that although these realities might not always be aligned with theoretical knowledge captured in [text]books, this strategy does offer the possibility of acquiring plausible insights into understanding phenomena. By connecting theoretical knowledge with personal lived experiences in open discussions, the outcome of such teaching can be used to bring them into contact with more accurate accounts of the world. For example, over the years, as we engaged with our students in the classroom on topics such as race, privilege, and inequality, we observed that although their responses cannot always be regarded as accurate, fair, and considerate of the feelings of others, their drawing on their experiences through discussions in the light of appropriate theory does disrupt the traditional and detached classroom space. In the process, active and critical engagement leads to their being active participants in the class. Yet it is also true that not every student is open to participating in class discussions on sensitive topics. For example, Peter, ${ }^{1}$ one of the first author's students responded, 'Sir, I am not interested in such topics, it is just too traumatic, and I do not feel like arguing'. But in postgraduate courses such as PGCE, one should expect students to engage critically with such issues.

Many scholars involved in teacher education programmes share similar sentiments and have reported on the difficulty they face in raising issues of race and racism with their pre-service teachers because of 'the general discomfort with the topic of difference' (McKinney 2005: 376). Allen and Rossatto (2009) and le Roux (2014) confirm this experience. Given the complexity of the issues with which students are confronted daily, we feel that it is important to deal with these topics in teacher education programmes in the light of their future role as knowledge workers in schools and because it is

\footnotetext{
${ }^{1}$ All names are pseudonymous.
} 
important to understand the ways in which power and privilege manifest in schools. For example, Murris (2016) reports how Chumani Maxwele, a student at the University of Cape Town, could not contain his emotions given that he had to face the statue of colonist Cecil John Rhodes every day. Consequently, he smeared the face of the statue with human waste collected from Khayelitsha. We believe that students should be allowed to tell their stories, reflect on events taking place around them, and reveal their views through interactive dialogue (Waghid 2010) to sensitise them to these realities and, in this way, encourage them to develop the critical stance that makes questioning structural oppression and racism desirable. In this way, they can become socially aware teachers who are able to disrupt, in the classroom, the role of social reproduction that schooling plays in society. Thus, to adequately prepare teachers for how to deal with such topical issues as race and racism and inequality and privilege, discursive pedagogies are required that will allow them to deliberate as participating actors to discover for themselves, through research and reflection, the concrete and context-sensitive nature of problems and conflicts in society. Accordingly, a pedagogy can be created that has students learn to articulate their standpoint through argumentation and take into account the perspectives of others so as to understand their standpoints and then deliberate on their arguments (Iwanyuanwu \& Ogunniyi 2020). The form of pedagogy needed in South African classrooms is what Zembylas and McGlyn (2012) call a pedagogy of discomfort. Such a pedagogy takes as its starting point that if we are to create the space for courageous conversations, no topic should be regarded as taboo. Since many of the legacies of apartheid education such as rote learning, conformity, and passivity still hold sway in the university (Koopman 2018; Waghid 2010) and because the classroom is similarly dominated by authoritarian pedagogies that do not allow the lived realities of the student to be given voice, this pedagogy has not been used effectively in it.

\section{What is a Critical Pedagogy of Discomfort?}

According to Bozalek et al. (2014), a critical pedagogy is a useful strategy for understanding teaching and learning about difference. Bozalek et al. (2014: 42) write, 'This pedagogy invites students to critique their deeply held assumptions, and to destabilise their views of themselves and their worlds'. These authors remind us that this process of learning can be painful and traumatic, but in being directed to the future, it gives participants an opportunity to revise 


\section{Sylvan Blignaut \& Oscar Koopman}

previously held views and arrive at new understandings. All members of the group are equally impacted by this discomfort whether they belong to the dominant or to marginalised groups. Leonardo and Porter (2010) support this view and observe that students have to work through the discomfort associated with the dialogue around difference, rather than avoiding it.

According to Biesta (2013), education involves risk and is not always secure, predictable, and risk-free. By giving students a voice and allowing them to articulate their own personal narratives we concur with him that education should not be risk-free and that we, as academics, should push the boundaries and make education in South Africa riskier by challenging our students in the classroom. Over the years as teachers we have attended many conferences and colloquia on decolonising the university landscape during which the argument has centred on the fact that our curricula and pedagogical practices are too evasive about issues of race and racism despite the tenacity of racism in South Africa as well as on the inertia among institutions about decolonising their curricula. Biesta (2013) argues against teachers who see their role as making the learning process as smooth and enjoyable as possible, and who will not ask difficult questions and confront inconvenient truths or introduce complex knowledge in the hope that students will leave as satisfied customers. Allen and Rossato (2009: 175) concur and acknowledge their scepticism and doubt 'that mere 'safe' discourse can be useful in achieving the radical transformation of the oppressor's consciousness'. Such an emphasis coheres well with our ideas that students should be challenged and confronted with critical discursive pedagogies. Carolissen (2011) argues along similar lines in that she also advocates for a pedagogy of discomfort with reference to the work of Zembylas and McGlyn (2012). Students should not be regarded simply as consumers of knowledge, but as active participants whose epistemic needs should be met as fully as possible in the learning spaces. Therefore, they should be encouraged to cultivate a critical disposition in discourse and to welcome knowledge that unsettles them (Biesta 2013).

To achieve this, Biesta (2010) identifies three domains within which educational purposes can be articulated. The first is the domain of qualifications, which has to do with the acquisition of knowledge, skills, values, and dispositions. The second is the domain of socialisation in which students are inducted into existing traditions and ways of doing and being. The third domain is subjectification, which has to do with the interest of education in the subjectivity, or what we think of as the subjectness, of those whom we 
educate. Biesta (2013) argues that subjectification has to do with emancipation and freedom, and with the responsibility that comes with such freedom. It is crucial, in our view, that we instil such a perspective in pre-service teachers who will eventually become teachers in the unequal schooling system of South Africa. Although all three domains are broadly relevant to this article, the third one, subjectification, is our central focus. We concur with Biesta's (2013) assertion that there is a weak relationship between so-called educational inputs and outcomes. He argues that teaching to match this model is slow, difficult, and frustrating, and the outcome of this process can be neither guaranteed nor secured. This view is consistent with our understanding that not all students will leave with the same understandings or will be willing to take on board some of the ideas that emerge in class through discussion and dialogue. Nothing is certain and guaranteed and everything is always characterised by risk simply because education is always an encounter between human beings. Biesta (2013: 55) continues in the same vein: 'To receive the gift of teaching, to welcome the unwelcome, to give a place to inconvenient truths and difficult knowledge, is precisely the moment where we give authority to the teaching we receive'.

\section{Methodology}

This study adopted a qualitative approach in which a purposive sample of PGCE students and one lecturer (the first author) who taught a course on Education Theory in a PGCE programme at a university in South Africa were studied over three months. This module is a component of the broader subject Educational Theory for which students register. The racial demography of the class that consisted of 71 students was diverse, but the majority were white. To push the boundaries of the students' understanding of issues of race, privilege, and equality, the lecturer/researcher adopted a critical pedagogy of discomfort to invite student responses. During the classes, he adopted the position of a participant observer. During such participant observation, as Crossman (2018) notes, the researcher becomes a subjective participant and an objective observer. By doing so the first author developed a good understanding of, and a familiarity with, the students' values and beliefs about race, racism, privilege, and inequality.

The main source of data were ethnographic fieldnotes that were written immediately or, at times, shortly after each class. These fieldnotes recorded the 
students' responses and the classroom interactions between students and lecturer based on fictitious scenarios such as newspaper articles about real-life experiences that underscored race, racism, privilege, and/or inequality. We used the interaction of students with the lecturer as well as the students' responses after every class to ascertain the effect of a critical pedagogy of discomfort as a teaching strategy. We then used their responses in our theorising on an embodied critical pedagogy of discomfort as a decolonising teaching strategy.

\section{A First-person Descriptive Narrative of the First Author's Experiences}

In one of the classes I used a fictional story to illuminate the appointment of black people to positions of employment in South Africa. More specifically, the scenario I used was an advertisement for a post in which the appointment criteria clearly emphasised that this position was reserved for a Black female candidate. One of the most striking responses came from John who said, 'Apartheid was abolished a long time ago, and we are all equal now. Why should black people be favoured over us? My parents are not rich but have worked hard to get where they are today'. Melinda, in support of John's views, commented, 'I am not a racist, but affirmative action discriminates against us as white students'. The responses of these students evoked a range of emotions in me ranging from irritability to frustration. It was clear that they were unaware of the implications of the continuation of their white privilege accrued historically through a system that procured advantages and entitlements for whites on the basis of their racial profile. They do not see that those who were discriminated against in the past and who suffered economically and otherwise should necessarily be at the centre of policies that advance them. Peter, a conservative Afrikaans-speaking male, who had resisted some of my course work readings as well as the particular pedagogical approach adopted in class at the beginning of the course, countered the views of the other two students by arguing that affirmative action could be justified in the light of a political system that discriminated against black people in the past based purely on their race. This statement caught me by surprise since Peter had opposed almost all the points I raised at the beginning of the course. At one point, for example, when I brought to class a news clip of a racist incident that was reported in the local newspaper that took place in a school in another province, he questioned 
the authenticity of the article and only reluctantly accepted it when Josie, another white student, convinced him that she came from the town where this happened so knew that it had taken place.

Most of the time the majority of the white students were more cautious and ambivalent, and it was difficult to pin down during the discussions their positionality in relation to being privileged.

Throughout the course, most of the white students in class often felt very uncomfortable with some of the topics that dealt with race and privilege but were often more willing to participate in discussions that dealt with class issues. They did not see the need for the past to be revisited since they felt that they had nothing to do with that past. There are salient warnings in the literature (Adorno 1998; Bonam et al. 2018) against such an attitude since the past cannot be avoided, especially in a country that has been severely fractured by racial fault lines that go back for more than 300 years. Adorno (1998) reminds us of the painful truth that a people without memory has no future. As we grapple with the future, as is presently the case in South Africa with demands from students for decolonisation and an African-purposed curriculum, it is essential that we interrogate the past lest we repeat the same mistakes in the future. As teacher educators in South Africa, it would be folly to avoid topics that create discomfort among primarily white students. It can also be argued that an approach involving a pedagogy of discomfort is desirable in the quest to humanise education in South Africa. This is entirely congruent with the ideas of Biesta (2013) as outlined above. Zembylas (2005) also reminds us that we cannot learn profoundly in meaningful ways without engaging in such a pedagogy.

\section{Discussion}

The responses of the students presented above suggest that there is a tension between their ontological and epistemological dispositions. Ontology and epistemology, from a realist perspective, exist as independent realities. In other words, an epistemological standpoint from this perspective views knowledge as something outside of the self and holds that there exists a reality or world that is different from one's personal views about reality. Four of the five students' responses come from a place within-their inner landscape of experiences - and this therefore forges their ontology around their inner personal views and perceptions. Since social justice requires an interrogation 
of different social realities and social structures, one of the aims of this pedagogical approach is to gauge the meaning and understanding of the ways in which students connect everyday realities of race, racism, privilege, and sporadic inequality with their personal views and experiences concerning the realities that surround them. When students share their views with their peers who belong to different races, backgrounds, classes and so forth, they learn to see ontology from a realist perspective, and, in the process, they might develop new understandings of how their world might be different from that of others. This is what we hope for. The focus of this pedagogical approach is not on how these students learn the coursework material, but on synchronising the very essence of a pedagogical experience with the existential nature of the experience. This pedagogical approach, according to Biesta (2013), is not always easy and is not without risks, because it involves active engagement and sharing of differing, even conflicting, views. Some of these views challenge the absolutisation and essentialisation of knowledge and the ways in which people perceive the world through firmly held beliefs and unquestioned assertions about how people think the world functions. The first author's experiences illuminate interesting questions and dilemmas for lecturers in postcolonial societies who teach students who are resistant to topics that deal with a problematic past.

This case study clearly points to the fragility, sensitivity, and vulnerability of the students, 26 years into a democratic dispensation, in a South African classroom where racial attitudes have not softened. This is illustrated by the fact that many students silently withdrew their participation in the class; they did not actively participate when sensitive topics on race, racism, privilege, and inequality were discussed. This is further substantiated by the remarks mentioned above. The findings also demonstrate that such attitudes can change; we saw this in Peter's response. He commenced this course with very rigid views about race and privilege, but these changed towards the end of it. Although the majority of his classmates did not share his views, this did not deter him and here we see evidence of authentic change (or what we would call deep change) from his earlier firmly held views on racist injustice.

The first author reported that a critical pedagogy at times made him feel exasperated at the end of his classes with this group of students and at times he questioned whether a progressive teaching approach could ever be successful. It remains our view, though, that it could become a valuable 
strategy in the racialised society that is South Africa. This is because the breaking down of social structures and people's knowledge of the society requires a shift from theoretical and logical constructs of knowledge to livedthrough ones, no matter how uncomfortable. According to Maton and Moore (2010), injustice is real ontology that is concrete and can be empirically demonstrated and should not be viewed only as a social construction developed within a practice through applied procedures. To tear down these misconstrued notions of reality means giving students a voice and fostering debate on issues even though they may be of a sensitive nature to some. The aim of a critical pedagogy is to unearth embodied knowledge with the aim of breaking down false beliefs and values that are deeply embedded in the minds of our students. This means providing them with what we think of as the knowledge tools to break down unjust and xenophobic practices built on racism, inequality, and privilege. It is against this background and the general resistance among white South African students to address the legacy of apartheid that it becomes obvious that university teaching in a postcolonial society is in need of more robust and provocative teaching approaches if we are to encourage curriculum transformation and decolonisation.

\section{Towards an Embodied Critical Pedagogy of Discomfort as a Decolonising Teaching Strategy}

Most of the time, many academics view their roles as experts in their respective fields and present their content as expert knowledge from the expert's pedestal in the classroom; this constrains the ways in which students as non-experts can engage with them. Such an approach stifles any possibility of critical engagement. More than three decades ago Maxine Green (1988) listed questions that are still relevant today if we want our students to become critical thinkers. She asked,

What is left for us then in this positivist, media-dominated, and selfcentred time? How, with so much acquiescence and so much thoughtlessness around us, are we to open people to the power of possibility? How, given the emphasis on preparing the young for a society of high technology, are we to move them to perceive alternatives, to look at things as if they could be otherwise? And why? And to what ends? (Green 1988: 55) 
In the light of Green's questions, we can say that in South Africa, mainly in the context of global capitalism, many people have become so self-centred, greedy, and self-righteous as to become disdainful of the merits of caring for the wellbeing of others in their communities or of any possible commitment to just social action. Our findings have shown that a critical pedagogy of discomfort might not be enough to bring about changes in the ways that students think about South Africa and the world. Therefore, we argue for a shift towards a more embodied critical pedagogy as a decolonising teaching strategy.

\section{Why an Embodied Approach?}

Every individual finds himself immersed in this world. As part of our existence, in terms of existentialist philosophy, we adopt a lifeworld in all its suffering and absurdity, and within it, common themes define our existence such as freedom, action, rebellion, and pain, to name a few. At the centre of all this is the individual thrust into this world where she or he must learn to cope and create meaning (Heidegger 1927/ 1967). According to Merleau-Ponty (1962/ 2005), we embody the scars of our experience through our active engagement with this world. Some of these scars were evident in the responses of some of the students. Drawing from Merleau-Ponty's philosophy, it is fair to argue that the truths the students hold are subjective and, because they held such strong beliefs, we cannot separate what they believe from who they are. Furthermore, these truths the students hold about issues of race, racism, privilege, and inequality can be viewed as the intersubjectivity of the communities from which they come. If the truth lies in the heart of the individual, this takes us to the notion of embodiment. Therefore, we feel that if we want to get to the truth of individuals' lived realities, we must adopt an embodied critical pedagogy of discomfort. This is because from a Heideggerian perspective humans should be viewed as conscious, suffering beings who learn to cope during difficulty.

To give an embodied critical pedagogy of discomfort a decolonising function we move beyond disciplinary knowledge to develop new knowledge agendas by deploying the body as a source of knowledge. By doing so (drawing on body knowledge), knowledge gains impetus from a localised context that is different from specialised, pure textbook laden knowledge. This is because the 
knowledge evolves from deep emotional scars and trauma, grief, mourning, and a sense of loss. We have to recognise that the intellectual agenda is not fixed in a particular discipline like psychology, medicine, law, and so forth but is situated in a social, context-laden process that is centred on the human body. Far from being radical, when dealt with in a dignified and caring way, this creates more in-depth epistemological dialogue. Although such a pedagogy can articulate the fears, concerns, challenges, successes, emotions, and so forth, it shifts the focus to the tactile nature of the body as an experiencing individual with a unique humanity, developed from listening, seeing, and feeling in the African context that is very different from that experienced on North American and European soil yet, ironically, it is these works that we often use in our classrooms. Simply put, the living subject and his or her engagement with things in the world through his or her capacity to listen, see, and feel with others should be the central focus of the pedagogical discourse.

Merleau-Ponty's notion of embodiment invites conversations and discussions about the body's passions such as love, hate, excitement, enthusiasm, anger, rage, agitation, fear, joy, powerlessness, and desire, among many others. The experiencing tactile body and the passionate body in an embodied critical pedagogy of discomfort allows the teacher and student to see, hear, and feel together so as to register one another's pain and suffering; through this they (teacher and student) can construct new meaning through understanding the otherness of each other. Such data or knowledge serves as a basis to deconstruct firmly held views and assumptions about the world and those with whom they live and becomes a powerful form of teaching for social justice. Evidence of this can be seen from the example of Peter who changed his beliefs and attitudes during the course. Since the focus of embodiment is on subjective truths and perceptions, students might learn to develop their own understanding of what they think to be the key issues of social justice and how they should be addressed. However, instead of suppressing the multiplicities of epistemologies, an embodied critical pedagogy of discomfort recognises the knowledge and personal views that students bring into the classroom. This is because embodiment does not seek active engagement of knowledge outside the self but shifts the focus to grapple with the inner landscape. This is the kind of approach needed to connect epistemologies with a well-planned and carefully facilitated pedagogy to create vibrant learning spaces for our students. 


\section{Acknowledgements}

We would like to thank our critical reader, Suriamurthee Maistry, and our two anonymous reviewers for their insightful comments on an earlier draft of this article.

\section{References}

Adorno, T.W. 1998. The Meaning of Working through the Past. Pickford, W. (trans.). New York: Columbia University Press.

Allen, R.L. \& C.A. Rossatto. 2009. Does Critical Pedagogy Work with Privileged Students? Teacher Education Quarterly 163-180.

Biesta, G.J.J. 2010. Good Education in an Age of Measurement: Ethics, Politics, Democracy. Boulder, CO: Paradigm Publishers.

Biesta, G.J.J. 2013. The Beautiful Risk of Education. Boulder, CO: Paradigm Publishers.

Bonam, C.M., V.N. Das, B.R. Coleman \& P. Salter. 2018. Ignoring History, Denying Racism: Mounting Evidence for the Marley Hypothesis and Epistemologies of Ignorance. https://doi.org/10.1177/1948550617751583 Bozalek, V., B. Leibowitz, R. Carolissen \& M. Boler 2014. A Pedagogy of Critical Hope in South African Higher Education. In Bozalek, V., B. Leibowitz, R. Carolissen \& M. Boler (eds.): Discerning Critical Hope in Educational Practices. London and New York: Routledge. https://doi.org/10.4324/9780203431115

PMid:23574731 MCid:PMC3635913

Carolissen, R. 2011. bell hooks and the Enactment of Emotion in Teaching and Learning across Boundaries: A Pedagogy of Hope? South African Journal of Higher Education 25.1: 157-167.

Crossman, A. 2018. Understanding Participant Observation Research: An Introduction to an Important Qualitative Research Method. Available at: www.thoughtco.com/participantobservation-research-3026557

(Accessed on 11 August 2020.)

Green, M. (1988) The Dialectic of Freedom. New York: Teachers College Press.

Heidegger, M. [1927] 1967. Being and Time. Macquarrie, J. \& E. Robinson (trans). Oxford: Basil Blackwell.

Iwuanyanwu, P.N. \& M.B. Ogunniyi 2020. Effects of Dialogical Argumentation Instructional Model on Pre-service Teachers' Ability to 
Solve Conceptual Mathematical Problems in Physics. African Journal of Research in Mathematics, Science and Technology Education 24,1: 129141. https://doi.org/10.1080/18117295.2020.1748325

Koopman, O. 2018. Science Education and Pedagogy in South Africa. New

York: Palgrave Macmillan. https://doi.org/10.3726/b11660

Koopman, O. 2019. Towards Decolonising Teaching Strategies: How to Domesticate and Infuse Western Science with Indigenous Knowledge. Journal of Education 74: 102-116.

https://doi.org/10.17159/2520-9868/i74a07

Le Grange, L. 2016. Decolonising the University Curriculum. South African Journal of Higher Education 30, 2: 1-12.

https://doi.org/10.20853/30-2-709

Leonardo, Z. \& R.K. Porter. 2010. Pedagogy of Fear: Toward a Fanonian Theory of 'Safety' in Race Dialogue. Race, Ethnicity and Education 13,

2: 139-157. https://doi.org/10.1080/13613324.2010.482898

Le Roux, A. 2014. 'We Were Not Part of Apartheid': Rationalisations Used by Four White Pre-Service Teachers to Make Sense of Race and their Own Racial Identities. South African Journal of Education 34, 2: 1-15. https://doi.org/10.15700/201412071137

Maton, K. \& R. Moore 2010. Introduction: Coalitions of Mind. In Maton, K.

\& R. Moore (eds.): Social Realism, Knowledge and the Sociology of Education. London: Continuum.

McKinney C. 2005. A Balancing Act: Ethical Dilemmas of Democratic Teaching within Critical Pedagogy. Educational Action Research 13, 3:

375-391. https://doi.org/10.1080/09650790500200318

Merleau-Ponty, M. 2005. Phenomenology of Perception. Smith, C. (trans.).

London: Routledge. (Original work published in 1962)

Murris, K. 2016. Rhodes must Fall: A Post-humanist Orientation to Decolonising Higher Education Institutions. South African Journal of Higher Education 30: 274-294. https://doi.org/10.20853/30-3-653

Ogunniyi, M.B. 2007. Teachers' Stances and Practical Argument regarding a Science Indigenous Knowledge Curriculum: Part 1. International Journal of Science Education 29, 8: 963-986.

https://doi.org/10.1080/09500690600931020

Ramrathan, L. 2010. From Responses to Theorising: Curriculum Genesis in South Africa from the Perspective of Critical Incidence Autoethnography. 
In Pinar, W. (ed.): Curriculum Studies in South Africa. New York: Palgrave Macmillan. https://doi.org/10.1057/9780230105508_4 Waghid, Y. 2010. Towards Authentic Teaching and Learning in Post-apartheid South Africa: In Defence of Freedom, Friendship and Democratic Citizenship. In Pinar, W. (ed.): Curriculum Studies in South Africa. New York: Palgrave Macmillan. https://doi.org/10.1057/9780230105508_7 Zembylas, M. 2005. Teaching with Emotion: A Postmodern Enactment. Greenwich, CT: Information Age Publishing.

Zembylas, M. \& C. McGlyn. 2012. Discomforting Pedagogies: Emotional Tensions, Ethical Dilemmas and Transformative Possibilities. British Educational Research Journal 38, 1: 41-59.

https://doi.org/10.1080/01411926.2010.523779

Sylvan Blignaut Professor Department of Postgraduate Studies Nelson Mandela University Port Elizabeth sylvan.blignaut@mandela.ac.za

Oscar Koopman

Senior Lecturer SP-FET Department, Faculty of Education Cape Peninsula University of Technology

Cape Town koopmano@cput.ac.za 